\title{
Characterisation of human coronavirus-NL63 nucleocapsid protein
}

\author{
Michael Berry', Taryn-Lee Manasse ${ }^{1}$, Yee-Joo Tan² and Burtram C. Fielding ${ }^{1 *}$ \\ ${ }^{1}$ Molecular Biology and Virology Laboratory, Department of Medical BioSciences, Faculty of Natural Sciences, \\ University of the Western Cape, Western Cape, South Africa. \\ ${ }^{2}$ Department of Microbiology, MD4, 5 Science Drive 2, Yong Loo Lin School of Medicine, National University of \\ Singapore, Singapore 117597.
}

Accepted 1 August, 2012

\begin{abstract}
Coronavirus $\mathbf{N}$ is a multifunctional protein that plays an essential role in enhancing the efficiency of virus transcription and assembly. This manuscript reports the analysis of HCoV-NL63 N protein by comparing the amino acid sequences of coronavirus $\mathrm{N}$-homologues. A $\sim 50 \mathrm{kDa}$ protein was expressed in both a mammalian cell and bacterial cell system that is similar in size to the predicted $\sim 42.6 \mathrm{kDa}$ HCoV-NL63 N protein. PSORTII identified two putative nuclear localisations signals and PONDR identified one disordered region in HCoV-NL63 N. The reported protein analysis serves as a prelude to laboratory analysis to understand the processing of HCoV-NL63 N.
\end{abstract}

Key words: HCoV-NL63, nucleocapsid protein, protein analysis, nuclear localisation signals, protein ordered/disordered regions.

\section{INTRODUCTION}

Genome sequencing technologies have resulted in large genome databases and the rate of genome sequencing has surpassed our ability to determine the function of the proteins these genomes encode. In silico analysis provides tools to predict possible functions of these proteins by comparing novel proteins of unknown function with proteins of known function, or by analyzing the unknowns using an algorithm based on information from proteins of known function. Thus, the theoretical analysis of proteins provide a useful framework that has given researchers the ability to predict the function of these proteins, which can then be verified with the use of in vitro and in vivo studies (MacKenzie et al., 2008; Mahotka et al., 2002). Coronaviruses are enveloped viruses of the Coronaviridae family in the order Nidovirales. Recently, the International Committee for Taxonomy of Viruses (ICTV) reported that the three traditional coronavirus groups are replaced by four genera, namely Alphacoronaviruses, Betacoronaviruses,

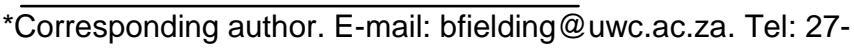
21-959 3620. Fax: 27-21-959 3125.
Gammacoronaviruses and Deltacoronaviruses (http:// talk.ictvonline.org/files/ictv_documents/m/msl/4090.aspx). Coronaviruses have single-stranded, positive sense RNA genomes, ranging in size from 25 to $30 \mathrm{kbs}$. The genomes typically encode for four structural proteins, spike (S), envelope (E), membrane (M) and nucleocapsid $(N)$. The coronavirus $\mathrm{N}$ protein is one of the most abundantly produced viral proteins within an infected cell. This protein has been shown to have several functions, including binding to viral RNA to form the ribonucleocapsid and is proposed to have roles in replication, transcription and translation. To date, coronavirus $\mathrm{N}$ proteins have been shown to cause deregulation of the host cell-cycle (Surjit et al., 2006; Wurm et al., 2001), inhibit the production of interferon (Kopecky-Bromberg et al., 2007), up-regulate the production of COX2 (Yan et al., 2006), up-regulate AP1 activity ( $\mathrm{He}$ et al., 2003), induce apoptosis in serum starved COS1-cells (Surjit et al., 2004a) and interact with various cellular proteins including cyclophilin $A$ (Luo et al., 2004) and hnRNP-A1 (Luo et al., 2005; Wang and Zhang, 1999), which may have possible pathological consequences.

Even though several studies have shown that the $\mathrm{N}$ - 
protein of members of Nidovirales localizes to the nucleus and/or nucleolus (Cawood et al., 2007; Hiscox et al., 2001; Timani et al., 2005; Wurm et al., 2001), others have shown that $\mathrm{N}$ localizes predominantly or exclusively to the cytoplasm (Rowland et al., 2005; Stohlman et al., 1983; You et al., 2005). This indicates that the localization of $\mathrm{N}$ to the nucleus or nucleolus is not a conserved property of nidoviruses (Rowland et al., 2005). The N-protein of coronaviruses is highly antigenic and reliably induces an antibody response (Mourez et al., 2007) and has therefore been recognized as an important target in the development of coronavirus diagnostics (Blanchard et al., 2011; Lee et al., 2008).

HCoV-NL63 was first isolated from the nasopharyngeal aspirate of a 7 month old infant from Holland (van der Hoek et al., 2004). The virus has since been shown to have a global distribution and is observed primarily in the winter season in temperate climates. To date, the virus has been associated with acute respiratory illness and croup in young children, the elderly and immunocompromised individuals (Oosterhof et al., 2010; Sung et al., 2010; van der Hoek et al., 2005, 2006). Clinical manifestations most frequently associated with HCoV-NL63 infections include cough, coryza, fever, sore throat, bronchiolitis, bronchitis, croup and pneumonia (Fielding, 2011; van der Hoek, 2007). To date, three groups have reported a fatal outcome following HCoVNL63 infection, indicating that this virus could be involved in more severe respiratory tract disease (Bastien et al., 2005; Cabeca and Bellei, 2012; Oosterhof et al., 2010); all of these cases had underlying suppressed or compromised immune systems.

Unfortunately, the virus is not well studied at a molecular level with only the spike (Lin et al., 2008, 2011; Mathewson et al., 2008) and ORF3 proteins (Fielding and Suliman, 2009; Muller et al., 2010) previously characterized. In this work, the HCoV-NL63 N was expressed in mammalian and bacterial systems. Various bioinformatics tools were used to analyze the HCoVNL63 N amino acid sequence. The importance of identified putative nuclear localization signals and disordered motifs were discussed. This manuscript reports the analysis of HCoV-NL63 $\mathrm{N}$ as a prelude to the molecular characterization of $\mathrm{N}$ in in vitro mammalian and bacterial cell systems.

\section{RESULTS AND DISCUSSION}

The HCoV-NL63 genome is approximately 27553 nucleotides in size, with the typical coronavirus genome organization. It produces six separate mRNAs, with all potential ORFs encoding for viral proteins. $N$ is expressed from distinct subgenomic (sg) mRNA 6, the most abundant sg mRNA (Pyrc et al., 2004). To determine the size of HCoV-NL63 N, recombinant GST-N was expressed in a bacterial system, purified by affinity column and treated with TEV to remove the GSTtag, according to the manufacturer's specification (Promega). Also, recombinant HCoV-NL63 N-HA was transfected and expressed in Cos-7 cells (Khan et al., 2006). SDS-PAGE analysis of purified bacterial expressed protein (Figure $1 \mathrm{~A}$ ) and Western Blot analysis of total mammalian cell lysate (Figure 1B) showed $\sim 50$ $\mathrm{kDa}$ proteins which is larger than the size of the $42.6 \mathrm{kDa}$ protein predicted by our initial analysis (http://www.sciencegateway.org/tools/ proteinmw.htm). This discrepancy in size showed that the protein was probably pre-, co- or post-translationally modified; the type of modification is currently being investigated.

Next, the amino acid sequence of HCoV-NL63 N was compared to other coronavirus $\mathrm{N}$ proteins (Table 1 ). HCoV-NL63 was shown to be most similar to the human coronavirus 229E N (43\% identity; $63 \%$ similarity). This was not totally unexpected, since previous molecular clock analysis estimate that HCoV-NL63 and HCoV-229E evolved from a most recent common ancestor in the $11^{\text {th }}$ century (Pyrc et al., 2006). Interestingly, HCoV-NL63 N also showed high amino acid similarity to the bat coronavirus HKU7 N (40\% identity; $57 \%$ similarity). As speculated previously (Fielding and Suliman, 2009), this high amino acid similarity raises interesting questions about the relationship between this human and bat coronaviruses. Woo and colleagues postulate that the ancestor of all present-day coronaviruses infected a bat and then jumped from that bat to a bird, or alternatively, first infected a bird and then jumped to a bat, evolving dichotomously. This bat coronavirus then jumped to another bat species, which in turn jumped to other bat species or other mammals, including humans. Each of these interspecies jumps resulted in the independent evolution of these coronaviruses and gave rise to the current coronavirus genera. In fact, present evidence suggests that the huge diversity of coronaviruses in bats make them excellent gene pools for group 1 and group 2 coronaviruses (Woo et al., 2009).

Comparative analysis using CLUSTAL $X$ version 2.0 (Larkin et al., 2007) of 10 coronavirus species identified a 9 amino acid region conserved between the $\mathrm{N}$ homologues, that is $\mathrm{FYY}(\mathrm{L} / \mathrm{T}) \mathrm{GTGP}$ (Figure 2). Conserved regions within a family of proteins is commonly indicative of structural and functional conservation, as well as an evolutionary relationship. The function of this sequence, if any, is yet to be elucidated. Since interactions between coronavirus RNA and N are assumed to predominantly take place at the nucleocapsid $\mathrm{N}$-terminal domain, the possible role of this conserved motif in RNA-N interaction will be studied. However, several other binding sites within $\mathrm{N}$ have also previously been identified, indicating that both $\mathrm{N}$ - and $\mathrm{C}$-terminal domains are probably involved in RNA binding (Chang et al., 2009).

Translocation of proteins from the cytoplasm through the nuclear pore complex and into the nucleoplasm is 

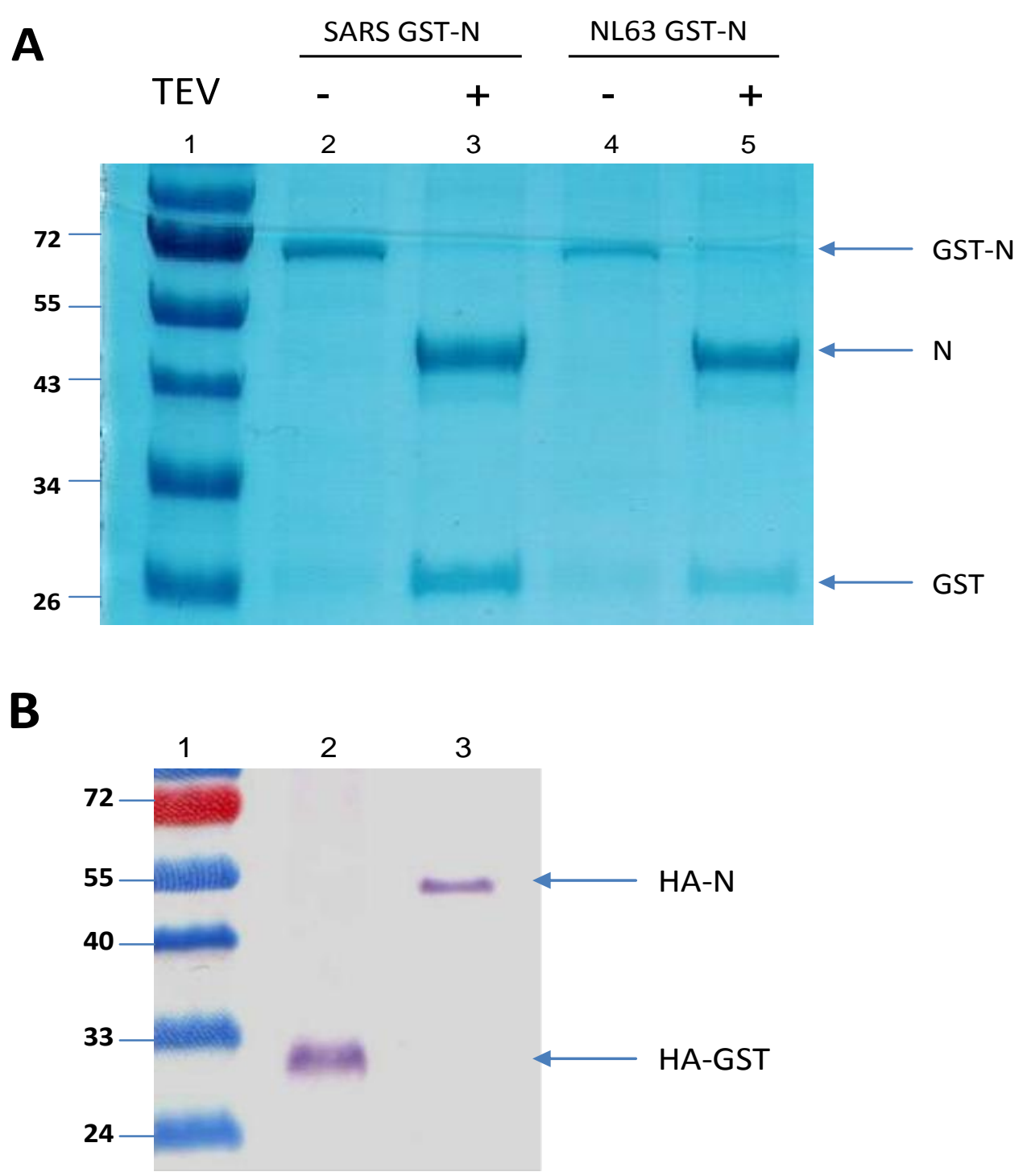

Figure 1. Expression of HCoV-NL63 N in: (A) a bacterial cell system. Cleavage of the GST-tag from SARS-CoV and HCoV-NL63 full length N using ProTEV protease (Promega). SARS-CoV N and NL63 N were reverse transcribed from viral RNA and PCR amplified using nucleocapsid specific primers. The $\mathrm{N}$-gene was cloned into the $\mathrm{pFlexi}^{\mathrm{TM}}$ protein expression vector (Promega), which appends an N-terminal GST affinity tag. Protein expression was induced by addition of $0.1 \%$ Rhamnose (Promega). Lane 1: Pre-stained molecular weight protein marker; Lane 2: SARS-CoV GST-N; Lane 3: SARS-CoV N with GST cleaved; Lane 4: HCoV-NL63 GST-N; Lane 5: HCoV-NL63 N with GST cleaved. SARS-CoV N was included as a control. (B) a mammalian cell system. Recombinant plasmid pCAGGS-N-HA (HCoV-NL63 N gene cloned into vector pCAGGS which appends an $\mathrm{N}$-terminal Haemagglutinin tag to expressed protein) was transfected with Lipofectamine 2000 (Invitrogen) into a COS-7 cell line (African green monkey cells) and grown at $37^{\circ} \mathrm{C}$ in $5 \% \mathrm{CO}_{2}$ for $16 \mathrm{~h}$. Cells were then lysed and the target protein detected on a Western Blot using rabbit anti-HA polyclonal (1:250) as primary antibody and goat anti-Rabbit polyclonal secondary antibody (1:1000).

initiated by nuclear localization signals (NLSs) on the protein binding to a NLS-binding site on importin- $\alpha$ of the host cell (Rowland et al., 2005). NLSs are rich in basic amino acids and conform to one of three types, that is, (i) monopartite pat4, (ii) monopartite pat7 or (iii) bipartitemotifs. Pat4 NLSs are recognized by the presence of 4 basic residues - either $K$ or $R$ or the presence of 3 basic residues $(K / R)$ and/or $(H / P)$. Pat7 NLSs are segments beginning with $P$ and followed within 3 residues by a basic segment containing $3 \mathrm{~K}$ or $\mathrm{R}$ residues out of 4 . On the other hand, bipartite NLSs begin with 2 basic residues, followed by a 10 residue 
Table 1. Comparison of HCoV-NL63 N amino acid sequence to homologues from selected coronavirus isolates. Identity values (\%) are shown in BOLD and similarity values (\%) are shown in ITALICS.

\begin{tabular}{cccccccccc}
\hline Coronavirus & SARS & MHV & IBV & OC43 & 229E & TGEV & PEDV & HKU1 & HKU7 \\
\hline \multirow{2}{*}{ NL63 } & $\mathbf{2 1}$ & $\mathbf{1 8}$ & $\mathbf{1 7}$ & $\mathbf{1 8}$ & $\mathbf{4 3}$ & $\mathbf{3 2}$ & $\mathbf{3 5}$ & $\mathbf{2 0}$ & $\mathbf{4 0}$ \\
& 34 & 31 & 31 & 32 & 63 & 51 & 50 & 34 & 57 \\
\hline
\end{tabular}

To identify homologues, the amino acid sequence of HCoV-NL63 N was compared to sequences in the GenBank database at the National Centre for Biotechnology by using the Basic Blast Search Server (Altschul et al., 1990). Subsequently, HCoV-NL63 N was aligned with selected coronavirus N proteins with CLUSTAL X version 2 (Larkin et al., 2007). The sequences aligned, with Genbank accession numbers in bold, were: HCoV-NL63: NL63 (DQ846901.1); SARS-CoV: SARS (AY360146.1); Mouse Hepatitis Virus: MHV (AAU06361); Infectious Bronchitis Virus: IBV (AAA46214), Human coronavirus OC43: HCoV-OC43 (AY585229.1); HCoV-229e: 229E (AAG48597); Transmissible gastroenteritis virus: TGEV (AAA47915); Porcine epidemic diarrhea virus:PEDV (AF353511); Human coronavirus HKU1: HKU1 (AAT98585) and Bat coronavirus HKU7: HKU7 (DQ666343).

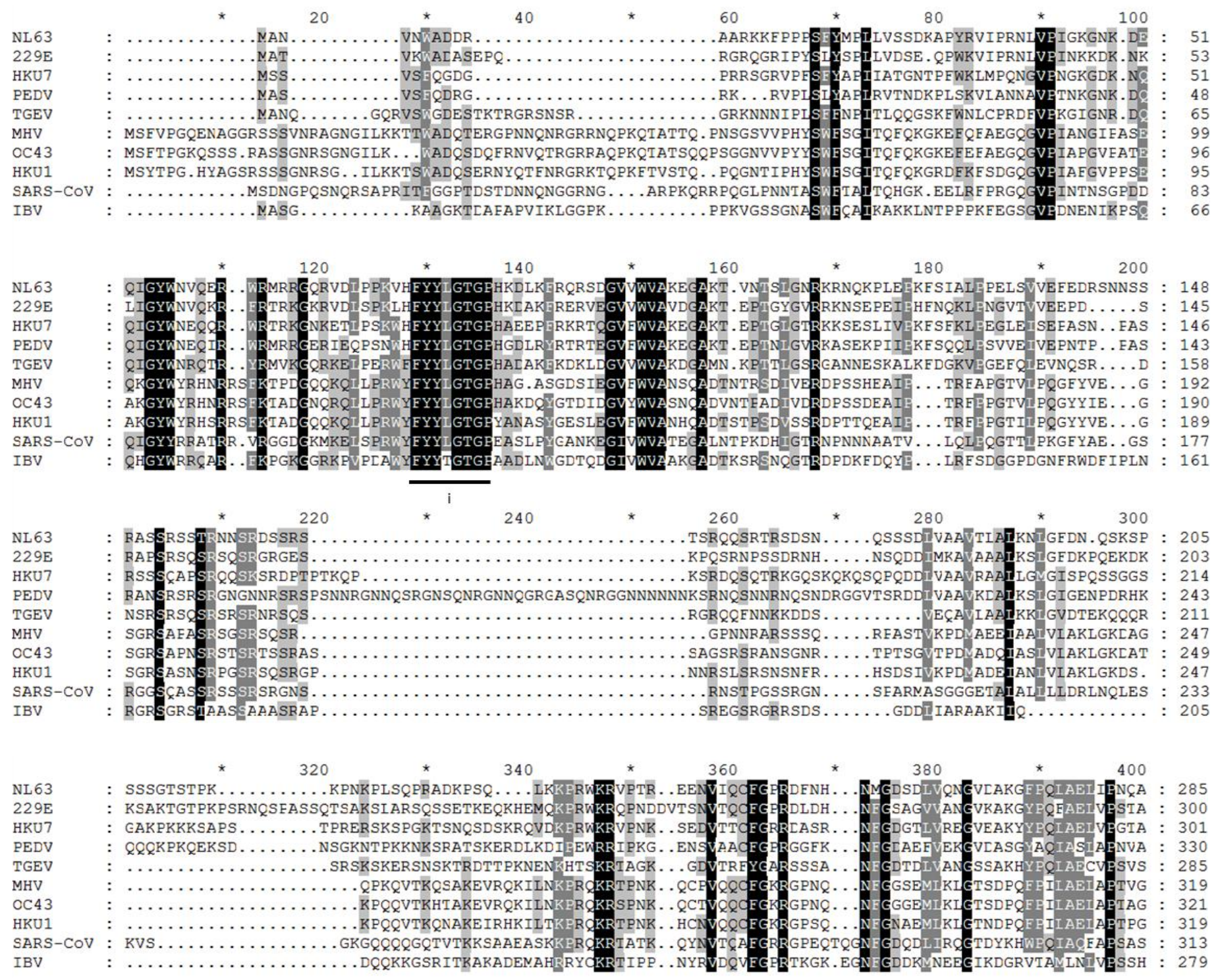

Figure 2. Comparative analyses of HCoV-NL63 N. Selected HCoV-NL63 N-homologues were aligned with CLUSTAL X version 2.0 (Larkin et al. 2007) and viewed with GENEDOC version 2.6.002 software (Nicholas et al; 1997). Shading indicates conserved regions and gaps were introduced to align sequences. Conserved region identified: (i) FYY(L/T)GTGP. N amino acid sequences were obtained from NCBI (accession numbers in brackets): HCoV-NL63 (DQ846901.1), SARS-CoV (AY360146.1), MHV (AAU06361), IBV (AAA46214), HCoV-OC43 (AY585229.1), HCoV-229E (AAG48597), TGEV (AAA47915), PEDV (AF353511), HKU1 (AAT98585) and HKU7 (DQ666343). 


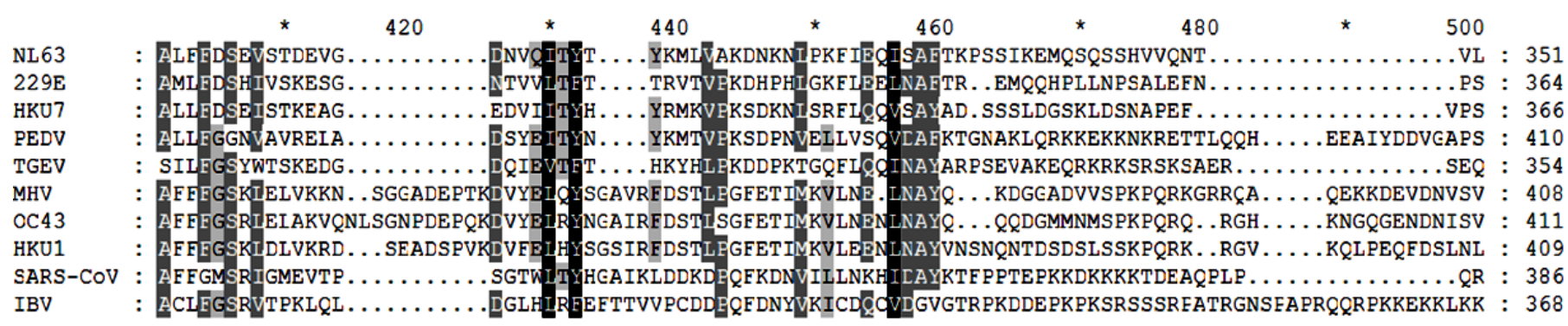

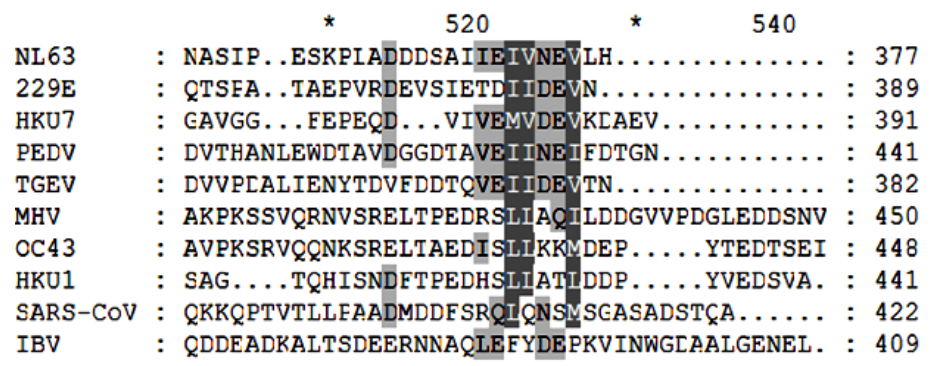

Figure 2. Continued.

spacer, which is then followed by another basic region composed of 3 basic residues out of 5 residues. PSORT II (http://www.genscript.com/psort/psort2.html) identified two possible NLSs for HCoV-NL63 N. A predicted pat4 motif was identified at amino acid position 232-235 (KKPR) and a predicted pat7 motif at position 234-240 (PRWKRVP); no bipartite motifs were identified for NL63 $\mathrm{N}$-protein.

Predictors of Natural Disordered Regions (PONDR) was used to predict possible disordered regions within HCoV-NL63 N. PONDR (http://www.pondr.com) uses several algorithms, including VL-XT, XL1-XT, VL3 and VSL1 to predict possible disordered regions. In this study, the VL-XT and VSL1 algorithms were used. VL-XT incorporates 3 feed-forward neural networks which are based on long disordered regions characterized by $\mathrm{x}$-ray chrystallographic data ( $\mathrm{Li}$ et al., 1999; Romero et al., 1997, 2001). The VSL1 utilizes two algorithms for short $(<$ $30 \mathrm{aa}$ ) and long (> 30aa) disordered regions and is trained on 1335 protein sequences (Obradovic et al., 2005). Even though in silico analysis is a good predictor of protein structure, errors can occur and findings must be substantiated with experimental evidence. The order/disorder state of HCoV-NL63 N was different to that of other coronavirus N-proteins, with HCoV-NL63 N having only one disordered region (residues 109 to 248) compared to the 2 to 3 disordered regions within other coronavirus N-proteins (Chen et al., 2005). Interestingly, many of the motifs and/or regions important for the interaction of SARS-CoV N with other proteins fall within these disordered regions (He et al., 2004; Huang et al., 2004; Luo et al., 2004; Surjit et al., 2004b). For this reason, residues 109 to 248 of HCoV-NL63 N could be crucial for interactions between HCoV-NL63 and other proteins.

In this study, molecular and bioinformatics tools were used to analyse HCoV-NL63 nucleocapsid protein by comparing it to selected coronavirus $\mathrm{N}$ proteins. Putative motifs that could be essential for the functioning of this protein have been identified; these are currently being verified in our laboratory. To our knowledge, this is the first manuscript reporting the molecular analysis of HCoV-NL63 N.

\section{ACKNOWLEDGEMENTS}

The authors wish to thank $\mathrm{Dr} \mathrm{M}$ Muller (University of Bonn, Germany) for the recombinant HCoV-NL63 N plasmid used for mammalian expression. HCoV-NL63 RNA was a kind gift from Prof Dr Lia van der Hoek (Netherlands). This research was funded by the National Research Foundation (NRF), South Africa. MB received financial support from NRF. Any opinion, findings and conclusions or recommendations expressed in this material are those of the authors and therefore the NRF does not accept any liability in regard thereto.

\section{REFERENCES}

Altschul SF, Gish W, Miller W, Myers EW Lipman DJ (1990). Basic local alignment search tool. J. Mol. Biol. 215:403-410.

Bastien N, Anderson K, Hart L, Van Caeseele P, Brandt K, Milley D, Hatchette T, Weiss EC, Li Y (2005). Human coronavirus NL63 infection in Canada. J. Infect. Dis. 191:503-506.

Blanchard EG, Miao C, Haupt TE, Anderson LJ, Haynes LM (2011). Development of a recombinant truncated nucleocapsid protein based immunoassay for detection of antibodies against human coronavirus OC43. J. Virol. Methods 177:100-106. 
Cabeca TK, Bellei N (2012). Human coronavirus NL-63 infection in a Brazilian patient suspected of $\mathrm{H} 1 \mathrm{~N} 12009$ influenza infection: description of a fatal case. J. clin. virol. official publ. Pan Am. Soc. Clin. Virol. 53:82-84.

Cawood R, Harrison SM, Dove BK, Reed ML, Hiscox JA (2007). Cell cycle dependent nucleolar localization of the coronavirus nucleocapsid protein. Cell Cycle 6:863-867.

Chang CK, Hsu YL, Chang YH, Chao FA, Wu MC, Huang YS, Hu CK, Huang TH (2009). Multiple nucleic acid binding sites and intrinsic disorder of severe acute respiratory syndrome coronavirus nucleocapsid protein: implications for ribonucleocapsid protein packaging. J. Virol. 83:2255-2264.

Chen H, Gill A, Dove BK, Emmett SR, Kemp CF, Ritchie MA, Dee M, Hiscox JA (2005). Mass spectroscopic characterization of the coronavirus infectious bronchitis virus nucleoprotein and elucidation of the role of phosphorylation in RNA binding by using surface plasmon resonance. J. Virol. 79:1164-1179.

Fielding BC (2011). Human coronavirus NL63: a clinically important virus? Future microbial. 6:153-159.

Fielding BC, Suliman T (2009) Comparative analysis of human coronavirus-NL63 ORF3 protein homologues. Afr. J. Biotechnol. 8:3175-3178

He R, Dobie F, Ballantine M, Leeson A, Li Y, Bastien N, Cutts T, Andonov A, Cao J, Booth TF, Plummer FA, Tyler S, Baker L, Li X (2004). Analysis of multimerization of the SARS coronavirus nucleocapsid protein. Biochem. Biophys. Res. Commun. 316:476483.

He R, Leeson A, Andonov A, Li Y, Bastien N, Cao J, Osiowy C, Dobie F, Cutts T, Ballantine M, Li X (2003). Activation of AP-1 signal transduction pathway by SARS coronavirus nucleocapsid protein. Biochem. Biophys. Res. Commun. 311:870-876.

Hiscox JA, Wurm T, Wilson L, Britton P, Cavanagh D, Brooks G (2001). The coronavirus infectious bronchitis virus nucleoprotein localizes to the nucleolus. J. Virol. 75:506-512.

Huang Q, Yu L, Petros AM, Gunasekera A, Liu Z, Xu N, Hajduk P, Mack J, Fesik SW, Olejniczak ET (2004). Structure of the N-terminal RNAbinding domain of the SARS CoV nucleocapsid protein. Biochemistry 43:6059-6063.

Khan S, Fielding BC, Tan TH, Chou CF, Shen S, Lim SG, Hong W, Tan YJ (2006) Over-expression of severe acute respiratory syndrome coronavirus $3 b$ protein induces both apoptosis and necrosis in Vero E6 cells. Virus. Res. (122)1-2: 20-27.

Kopecky-Bromberg SA, Martinez-Sobrido L, Frieman M, Baric RA, Palese $P$ (2007). Severe acute respiratory syndrome coronavirus open reading frame (ORF) 3b, ORF 6 , and nucleocapsid proteins function as interferon antagonists. J. Virol. 81:548-557.

Larkin MA, Blackshields G, Brown NP, Chenna R, McGettigan PA, McWilliam H, Valentin F, Wallace IM, Wilm A, Lopez R, Thompson JD, Gibson TJ, Higgins DG (2007). Clustal W and Clustal X version 2.0. Bioinformatics 23:2947-2948.

Lee HK, Lee BH, Dutta NK, Seok SH, Baek MW, Lee HY, Kim DJ, Na YR, Noh KJ, Park SH, Kariwa H, Nakauchi M, Mai le Q, Heo SJ, Park $\mathrm{JH}$ (2008). Detection of antibodies against SARS-Coronavirus using recombinant truncated nucleocapsid proteins by ELISA. J. Microbiol. Biotechnol. 18:1717-1721.

Li X, Romero P, Rani M, Dunker AK, Obradovic Z (1999). Predicting Protein Disorder for N-, C-, and Internal Regions. Genome informatics. Workshop Genome Inform. 10:30-40.

Lin HX, Feng Y, Tu X, Zhao X, Hsieh CH, Griffin L, Junop M, Zhang C (2011). Characterization of the spike protein of human coronavirus NL63 in receptor binding and pseudotype virus entry. Virus Res. 160:283-293.

Lin HX, Feng Y, Wong G, Wang L, Li B, Zhao X, Li Y, Smaill F, Zhang C (2008). Identification of residues in the receptor-binding domain (RBD) of the spike protein of human coronavirus NL63 that are critical for the RBD-ACE2 receptor interaction. J. Gen. Virol. 89:10151024.

Luo C, Luo H, Zheng S, Gui C, Yue L, Yu C, Sun T, He P, Chen J, Shen J, Luo X, Li Y, Liu H, Bai D, Yang Y, Li F, Zuo J, Hilgenfeld R, Pei G, Luo H, Chen Q, Chen J, Chen K, Shen X, Jiang H (2005). The nucleocapsid protein of SARS coronavirus has a high binding affinity to the human cellular heterogeneous nuclear ribonucleoprotein A1.
FEBS Lett. 579:2623-2628.

MacKenzie JJ, Gomez ND, Bhattacharjee S, Mann S, Haldar K (2008). A Plasmodium falciparum host-targeting motif functions in export during blood stage infection of the rodent malarial parasite Plasmodium berghei. PLoS One. 3: e2405.

Mahotka C, Liebmann J, Wenzel M, Suschek CV, Schmitt M, Gabbert HE, Gerharz CD (2002). Differential subcellular localization of functionally divergent survivin splice variants. Cell Death Differ. 9: 1334-1342.

Mathewson AC, Bishop A, Yao Y, Kemp F, Ren J, Chen H, Xu X, Berkhout B, van der Hoek $L$, Jones IM (2008). Interaction of severe acute respiratory syndrome-coronavirus and NL63 coronavirus spike proteins with angiotensin converting enzyme-2. J. Gen. Virol. 89:2741-2745.

Mourez T, Vabret A, Han Y, Dina J, Legrand L, Corbet S, Freymuth F (2007). Baculovirus expression of HCoV-OC43 nucleocapsid protein and development of a Western blot assay for detection of human antibodies against HCoV-OC43. J. Virol. Methods 139:175-180.

Muller MA, van der Hoek L, Voss D, Bader O, Lehmann D, Schulz AR, Kallies S, Suliman T, Fielding BC, Drosten C, Niedrig M (2010). Human coronavirus NL63 open reading frame 3 encodes a virionincorporated N-glycosylated membrane protein. Virol. J. 7:6.

Nicholas KB, Nicholas HB Jr., Deerfield DW (1997). GeneDoc: analysis and visualization of genetic variation. EMBNEW News 4:14.

Obradovic Z, Peng K, Vucetic S, Radivojac P, Dunker AK (2005). Exploiting heterogeneous sequence properties improves prediction of protein disorder. Proteins 61(Suppl 7):176-182.

Oosterhof L, Christensen CB, Sengelov H (2010). Fatal lower respiratory tract disease with human corona virus NL63 in an adult haematopoietic cell transplant recipient. Bone marrow transplant. 45:1115-1116

Pyrc K, Dijkman R, Deng L, Jebbink MF, Ross HA, Berkhout B, van der Hoek $L$ (2006). Mosaic structure of human coronavirus NL63, one thousand years of evolution. J. Mol. Biol. 364:964-973.

Pyrc K, Jebbink MF, Berkhout B, van der Hoek L (2004). Genome structure and transcriptional regulation of human coronavirus NL63. Virol. J. 1:7.

Romero P, Obradovic Z, Dunker K (1997). Sequence Data Analysis for Long Disordered Regions Prediction in the Calcineurin Family. Genome informatics. Workshop Genome Inform. 8:110-124.

Romero P, Obradovic Z, Li X, Garner EC, Brown CJ, Dunker AK (2001). Sequence complexity of disordered protein. Proteins 42:38-48.

Rowland RR, Chauhan V, Fang Y, Pekosz A, Kerrigan M, Burton MD (2005). Intracellular localization of the severe acute respiratory syndrome coronavirus nucleocapsid protein: absence of nucleolar accumulation during infection and after expression as a recombinant protein in vero cells. J. Virol. 79:11507-11512.

Stohlman SA, Fleming JO, Patton CD, Lai MM (1983). Synthesis and subcellular localization of the murine coronavirus nucleocapsid protein. Virology 130:527-532.

Sung JY, Lee HJ, Eun BW, Kim SH, Lee SY, Lee JY, Park KU, Choi EH (2010). Role of human coronavirus NL63 in hospitalized children with croup. Pediatr. infect. dis. J. 29:822-826.

Surjit M, Liu B, Chow VT, Lal SK (2006). The nucleocapsid protein of severe acute respiratory syndrome-coronavirus inhibits the activity of cyclin-cyclin-dependent kinase complex and blocks $S$ phase progression in mammalian cells. J. Biol. Chem. 281:10669-10681.

Surjit M, Liu B, Jameel S, Chow VT, Lal SK (2004a). The SARS coronavirus nucleocapsid protein induces actin reorganization and apoptosis in COS-1 cells in the absence of growth factors. Biochem. J. 383:13-18.

Surjit M, Liu B, Kumar P, Chow VT, Lal SK (2004b). The nucleocapsid protein of the SARS coronavirus is capable of self-association through a C-terminal 209 amino acid interaction domain. Biochem. Biophys. Res. Commun. 317:1030-1036.

Timani KA, Liao Q, Ye L, Zeng Y, Liu J, Zheng Y, Yang X, Lingbao K, Gao J, Zhu Y (2005). Nuclear/nucleolar localization properties of Cterminal nucleocapsid protein of SARS coronavirus. Virus Res. 114:23-34.

van der Hoek L (2007). Human coronaviruses: what do they cause? Antivir. ther. 12:651-658.

van der Hoek L, Pyrc K, Jebbink MF, Vermeulen-Oost W, Berkhout RJ, 
Wolthers KC, Wertheim-van Dillen PM, Kaandorp J, Spaargaren J, Berkhout B (2004). Identification of a new human coronavirus. Nat. Med. 10:368-373.

van der Hoek $L$, Sure $K$, Ihorst G, Stang A, Pyrc K, Jebbink MF, Petersen G, Forster J, Berkhout B, Uberla K (2005). Croup is associated with the novel coronavirus NL63. PLoS medicine 2: e240. van der Hoek L, Sure K, Ihorst G, Stang A, Pyrc K, Jebbink MF, Petersen G, Forster J, Berkhout B, Uberla K (2006). Human coronavirus NL63 infection is associated with croup. Adv. Exp. Med. Biol. 581:485-491.

Wang Y, Zhang X (1999). The nucleocapsid protein of coronavirus mouse hepatitis virus interacts with the cellular heterogeneous nuclear ribonucleoprotein A1 in vitro and in vivo. Virology 265:96-109.

Woo PC, Lau SK, Huang Y, Yuen KY (2009). Coronavirus diversity, phylogeny and interspecies jumping. Exp. Biol. Med. (Maywood) 234:1117-1127.
Wurm T, Chen H, Hodgson T, Britton P, Brooks G, Hiscox JA (2001). Localization to the nucleolus is a common feature of coronavirus nucleoproteins, and the protein may disrupt host cell division. J. Virol. 75:9345-9356.

Yan X, Hao Q, Mu Y, Timani KA, Ye L, Zhu Y, Wu J (2006). Nucleocapsid protein of SARS-CoV activates the expression of cyclooxygenase-2 by binding directly to regulatory elements for nuclear factor-kappa B and CCAAT/enhancer binding protein. Int. J. Biochem. Cell Biol. 38:1417-1428.

You J, Dove BK, Enjuanes L, DeDiego ML, Alvarez E, Howell G, Heinen P, Zambon M, Hiscox JA (2005). Subcellular localization of the severe acute respiratory syndrome coronavirus nucleocapsid protein. J. Gen. Virol. 86:3303-3310. 